\title{
THE SCHOOL'S FUNCTION AND THE INFLUENCE OF CULTURAL CAPITAL ON STUDENTS' PERFORMANCE
}

\section{A FUNÇÃO DA ESCOLA E A INFLUÊNCIA DO CAPITAL CULTURAL NO DESEMPENHO ESCOLAR}

\section{LA FUNCIÓN DE LA ESCUELA Y LA INFLUENCIA DEL CAPITAL CULTURAL EN EL RENDIMIENTO ESCOLAR}

\author{
Andreza Olivieri Lopes Carmignolli ${ }^{1}$ \\ Luci Regina Muzzeti² \\ Maria Fernanda Celli de Oliveira ${ }^{3}$
}

\begin{abstract}
This is an excerpt of a master's dissertation titled "The influence of cultural, social and economic capitals on the students' school trajectory success". It aimed to analyse how cultural capital influences the students' school performance through their family's mores and school experiences, when observing their behaviours regarding musical styles, reading practices and sports activities. The family environment is where people initially acquire cultural capital, being legitimized within a set of socially recognized knowledge and cultural assets. The studies of Pierre Bourdieu through the concepts of habitus, cultural, economic and social capital guided the theoretical reference. We chose the qualitative research method named Bourdieusian praxeology, because it is related to the restructuring of the habitus. The results of the work show how important is the partnership between the school and the family for a successful school performance.
\end{abstract}

Keywords: School's role. Cultural capital. School performance. Habitus.

Resumo: Este trabalho é um recorte da dissertação de mestrado intitulada $A$ influência dos capitais cultural, social e econômico no sucesso da trajetória escolar, que teve como objetivo analisar como o desempenho escolar é influenciado pelo capital cultural, através dos costumes familiares e experiências escolares observadas nos comportamentos dos alunos por estilos musicais, práticas de leitura e atividades esportivas. O capital cultural é adquirido inicialmente no meio familiar e é legitimado dentro de um conjunto de conhecimentos e bens culturais reconhecidos socialmente. O referencial teórico deste trabalho foi norteado pelos

\footnotetext{
${ }^{1}$ São Paulo State University (UNESP). Araraquara. São Paulo, Brazil.

2 São Paulo State University (UNESP). Araraquara. São Paulo, Brazil.

${ }^{3}$ São Paulo State University (UNESP). Araraquara. São Paulo, Brazil.
} 
estudos de Pierre Bourdieu por meio dos conceitos de habitus, capital cultural, capital econômico e capital social. O método utilizado foi o praxiológico bourdesiano, de base qualitativa, uma vez que se relaciona com a reestruturação do habitus. Os resultados do trabalho mostram a importância da parceria entre a escola e a família para um desempenho escolar exitoso.

Palavras-chave: Papel da escola. Capital cultural. Desempenho escolar. Habitus.

Resumen: Este artículo es un extracto de la tesis del máster titulada $A$ influência dos capitais cultural, social e econômico no sucesso da trajetória escolar [La influencia de los capitales culturales, sociales y económicos sobre el éxito de la trayectoria escolar], que tenía como objetivo analizar cómo el rendimiento escolar está influenciado por el capital cultural, a través de las costumbres familiares y experiencias escolares observadas en los comportamientos de los estudiantes por estilos musicales, prácticas de lectura y actividades deportivas. El capital cultural se adquiere inicialmente en el entorno familiar y se legitima dentro de un conjunto de conocimientos y bienes culturales socialmente reconocidos. El marco teórico de este trabajo fue guiado por los estudios de Pierre Bourdieu a través de los conceptos de habitus, capital cultural, capital económico y capital social. El método utilizado fue el praxiológico bourdesiano, de base cualitativa, ya que se refiere a la reestructuración del habitus. Los resultados del trabajo muestran la importancia de la asociación entre la escuela y la familia para un rendimiento escolar exitoso.

Palabras clave: Papel de la escuela. Capital Cultural. Rendimiento escolar. Habitus.

\section{INTRODUCTION}

Large-scale estimates are wide-ranging tools used to evaluate the Brazilian educational system and can be divided into diagnostic tests, formative and summative assessments, being used depending on the educational purpose. It is worth remembering that, in our country, the evaluation processes were reconsidered important only after the re-democratisation of education and its universalisation.

According to Bloom, Hastings and Madaus (1983) the main objective of formative assessment is to determine the degree to which the student has acquired certain learning; its purpose is based on the results presented, to plan differentiated work strategies to assist the student in overcoming his difficulties and acquiring learning.

The formative evaluation takes into account the individual and their specificity, combining the criteria of achievement with criteria referenced to the student (for example, the teacher may take into account specific difficulties of a given student, the effort, the evolution that the student 
presents) (HARLEN; JAMES, 1997 apud SANTOS, 2016, p. 641), our translation $)^{4}$.

We saw during the in-process learning assessments (AAP) and in the Focus Learning Platform, that both resources are used at public schools in São Paulo to monitor the students' learning.

The authors define that the summative assessment aims are verifying whether learning expectations have been achieved throughout the course or part of it. Large-scale assessments are used to monitor the result of a process, i.e., analysing the knowledge acquired by the student at the end of the year. As example, we have the evaluations of SARESP, SAEB, PROVA BRASIL and data from the School Census, all instruments used to measure the performance of students and schools

Diagnostic assessments, on the other hand, aim to classify students according to their skills and competences based to their learning history, which is clear in the written surveys carried out with students in the first year (during the early years), in the first weeks of class to check each student's writing hypotheses.

These estimates show the teacher the routes used and which concepts need to be resumed so the students can acquire knowledge; it is worth mentioning that the students' knowledge is prioritized individually during this evaluation.

Bloom, Hastings and Madaus (1983) emphasizes that the diagnosis demands the location of the students' knowledge to identify the underlying causes of learning disabilities, as teaching evolves, enabling the construction of new knowledge.

The school performance is measured by assessment instruments which show relevant aspects in the course of the teaching-learning process and aim to point out educational improvements for quality teaching; remembering that the term school performance is related to the knowledge acquired by the student and the term school development is the ability that the student has in acquiring knowledge.

The work aimed to analyse the school - family relationship in school performance; considering aspects related to knowledge acquisition, family profile, cultural heritage and social mobility.

\footnotetext{
${ }^{4}$ A avaliação formativa toma em linha de conta o indivíduo e a sua especificidade, combinando os critérios de realização com critérios referenciados ao aluno (por exemplo, o professor pode tomar em linha de conta dificuldades específicas de um dado aluno, o esforço que fez, a evolução que apresenta) (HARLEN; JAMES, 1997 apud SANTOS, 2016, p. 641).
} 


\section{THEORETICAL REFERENCE}

We guided the theoretical framework by the studies of Pierre Bourdieu by the concepts of habitus, ethos, cultural capital, economic capital and social capital.

Bourdieu (2003) says that the school becomes responsible for the legitimation of social inequalities, since the teaching organization selects only successful students, as noted in the following citation, "[...] the attitudes of members from different social classes, parents or children regarding school, culture and the future offered by studying are expressions of the implicit or explicit value system, resulting from the occupied social position" (BOURDIEU, 2003, p. 50, our translation).

The student's performance during their school career is the result of a set of factors that include the cultural heritage received in the family environment; cultural capital; economic capital; parental participation in school activities and the role of the school.

Cultural heritage, according to Muzzeti (1997) is defined by the inheritance received directly from the family environment, understood as a set of knowledge, attitudes, dispositions, information, which vary according to the social origin of the members of different groups.

From their initial formation in a social and family environment that corresponds to a specific position in the social structure, individuals would incorporate a set of dispositions for the typical action of that specific position (a family or class habitus) which would start guiding them over time and in the most varied action environments (NOGUEIRA; NOGUEIRA, 2002, p. 20, our translation $)^{5}$.

Cultural heritage is not only related to the transmission from one generation to another of behaviours but also manners, skills and attitudes acquired involuntarily, that is, only by living together. Thus, "we understand the cultural heritage as a set of values, knowledge and information which are constituted by the cultural capital that differentiates them from other groups" (OLIVEIRA et al., 2017, p. 99, our translation).

According to Nogueira and Nogueira (2002, p. 22, our translation $)^{6}$,

\footnotetext{
${ }^{5}$ A partir de sua formação inicial em um ambiente social e familiar que corresponde a uma posição específica na estrutura social, os indivíduos incorporariam um conjunto de disposições para a ação típica dessa posição (um habitus familiar ou de classe) e que passaria a conduzi-los ao longo do tempo e nos mais variados ambientes de ação (NOGUEIRA; NOGUEIRA, 2002, p. 20).

${ }^{6}$ A bagagem herdada por cada indivíduo não poderia ser entendida, no entanto, simplesmente, como um conjunto mais ou menos rentável de capitais que cada indivíduo utiliza a partir de critérios definidos de modo
} 
The baggage inherited by each individual could not be understood simply as a more or less profitable set of capitals that each individual use based on criteria defined in an idiosyncratic approach. As already said by Bourdieu, each social group would constitute a specific system of dispositions for action, which would be transmitted to individuals in the habitus form according to the objective conditions that characterise its position in the social structure.

Habitus is the objectively classifiable practices-generating principle, ranked by a system of practices where different existence conditions produces different habits which reverberates in life styles. In other words, habitus is also a structured construction that organizes practices and their perceptions in division and logical classes principle, organized by the social world perception (BOURDIEU, 2003).

\begin{abstract}
Observing the predominance of adulthood's primary habitus elements demands a wide investigation effort, as the agent may fragmentally manifest on different capitals that compose the notion of habitus such as linguistic, social, cultural and economic capitals. The subtlety and naturalness with which these elements emerge in the agent's daily life are proportional to the domain, familiarity and fluidity in which these signs, structures and strategic senses were appropriated during their trajectory. The difficulty in observing these elements, according to Bourdieu, is also metamorphosed by the disguises with which they emerge as the form of biological heredity (MANZAN; MUZZETI; SUFICIER, 2012, p. 143).
\end{abstract}

Thus,

We infer that pondering about the socialisation in the Bourdiesian patterns requires thinking of the agent as a result of some specific habitus incorporation, being intrinsically associated to movements on a specific field, where the agent occupies a delimited position, allowing them to develop dispositions according to their capital volume (MELO, 2015, p. 195) 8

\footnotetext{
idiossincrático. Como já foi dito, segundo Bourdieu, cada grupo social, em função das condições objetivas que caracterizam sua posição na estrutura social, constituiria um sistema específico de disposições para a ação, que seria transmitido aos indivíduos na forma do habitus (NOGUEIRA; NOGUEIRA 2002, p. 22).

${ }^{7}$ A observação da predominância de elementos do habitus primário na vida adulta demanda de um amplo esforço de investigação, pois o agente poderá manifestá-lo de maneira fragmentada nos diferentes capitais que compõem a noção de habitus, tais como capital linguístico, social, cultural e econômico. A sutileza e a naturalidade com a qual esses elementos emergem no cotidiano do agente são proporcionais ao domínio, familiaridade e fluidez com que esses signos, estruturas e sensos estratégicos foram apropriados em sua trajetória. A dificuldade de observação desses elementos, conforme Bourdieu, também é metamorfoseada pelos disfarces com o qual emergem sob a aparência de hereditariedade biológica (MANZAN; MUZZETI; SUFICIER, 2012, p. 143).
}

\footnotetext{
${ }^{8}$ Inferimos que refletir sobre socialização nos padrões bourdiesianos demanda pensar no agente como resultante da incorporação de um determinado habitus que, por sua vez, está intrinsecamente ligado ao trânsito em um campo específico, o qual ele ocupa uma posição demarcada que lhe permite desenvolver disposições de acordo com o seu volume de capital (MELO, 2015, p. 195).
} 
The concept of cultural capital was conceived by Bourdieu (2003) to explain the inequalities among children in the school space, considering that individuals who inherit a rich and diversified cultural heritage are very likely to have a successful school trajectory by mastering the cultured language and socially recognized symbolic codes. The transmission of cultural capital will be very likely affected by the result of the family cultural level and a successful school trajectory.

Cultural privilege becomes evident when it comes to the familiarity regarding works of art, which can only come from regularly attending theatres, museum and concerts. (BOURDIEU, 2003). Thus, "to convert family's cultural capital into personnel cultural capital, it is necessary to mobilise both students and their parents" (MASSI; MUZZETI; SUFICIER, 2017, p. 1861, our translation).

Cultural capital is divided into three states: the incorporated state (regard to durable predispositions, expressed by body postures, verbal characteristics, ways of dressing and behaving), the objectified state (related to the possession of cultural goods, socially recognized by the dominant culture, e.g., books, works of art) and the institutionalized state (related to diplomas and certificates).

In this way, we can say that cultural capital,

[...] represents an exercise of incorporation and internalisation which occurs initially in the family sphere, serving as a link between individuality and the family throughout their existence. Because this transmission occurs within the family, we can infer that it is a cultural heritage, i.e., a set of values and morals passed on to the offspring (OLIVEIRA et al., 2017, p. 101, our translation) ${ }^{9}$.

The contact of individuals with books, works of art and classical music will transmit one of the cultural capital states'; this contact is possible through the economic capital, by inheriting or acquiring. It is worth mentioning that the incorporation of cultural capital is only possible if the individual masters the symbolic codes to enjoy material goods.

${ }^{9}[. .$.$] representa um exercício de incorporação e interiorização, que se dá inicialmente no âmbito familiar, servindo$ como um elo entre a individualidade e a família por toda sua existência. Por essa transmissão se dar no seio familiar, podemos inferir que trata-se de uma herança cultural, ou seja, um conjunto de valores e moral passados à prole (OLIVEIRA et al., 2017, p. 101). 
The economic capital corresponds to an extension of the modern notion of equality; which is valued by monetary or physical units such as real estate, automobiles, equipment, miscellaneous possessions, among other things (LEBARON, 2017).

The remuneration, properties, material goods and bonds found in the social environment are some of the differentiating principles. Thus, we can say that economic capital is connected to cultural and social capital.

Social capital is known as a set of resources related to owning institutionalized relations of knowledge, recognising when the individual starts to benefit from the generated social bonds. These possessions may cease to exist if the individuals involved in these relationships stop maintaining the work which generated the social bonds.

To Grün (2017), capital works differently in each space or field in which it is used, becoming evident for other capitals, but not very intuitive for the economic one. For example, in religious and intellectual contexts, economic capital has no value.

Bourdieu (2003, p. 53, our translation $)^{10}$ explains that:

"[...] making the school system as a factor of the social movement, according to the ideology of the liberating school when, on the contrary, everything tends to show that it is one of the most effective factors of social conservation, as it provides the appearance of legitimate social inequalities, sanctioning cultural heritage and treating the social gift as natural".

The school aims to promote knowledge, defined as a factor of social mobility. The operating structures of the education system are characterized by the means of production and reproduction according to institutional conditions, whose relations between groups or classes contribute to social reproduction.

According to Bourdieu (2003), schools welcome a greater number of students with great difficulties under the domain of linguistic codes during the first half of the twentieth century, which are recognized as social skills and indispensable in the dominant culture.

Under this point of view, the school tends to ensure knowledge, determining what deserves or not to be prioritized within the educational guidelines, i.e., what needs to be learned, which resources will be necessary for learning to become true, fulfilling its social

\footnotetext{
${ }^{10}[\ldots]$ tomando o sistema escolar como um fator de mobilidade social, segundo a ideologia da escola libertadora, quando, ao contrário, tudo tende a mostrar que ele é um dos fatores mais eficazes de conservação social, pois fornece a aparência de legitimidade às desigualdades sociais, e sanciona a herança cultural e o dom social tratado como dom natural (BOURDIEU, 2003, p. 53).
} 
function in a society which distinguishes cultural goods from legitimate or illegitimate ones. Thus, Kinchescki, Grimm and Sossai (2015, p. 249, our translation) claim that "the meanings which the pedagogical action instils are inferred from a logical or biological universal principle, and it is by its relation of power and reproduction that the dominant cultural agency is always in a dominant position".

In this way, the school will be considered as a factor of social mobility that will act on the whole teaching process, legitimizing the learning mechanism in the different degrees of development.

The words of Bourdieu (1992, p. 57, our translation) are "through the work carried out by the school system, the State exerts a unifying action on the forms and categories of thoughts, under the sign of legitimate national culture, the basis of the idea of a national society".

Carmignolli (2019) shows on their research that when the school performs its role it provides all members of society with the development of cultural practices considered nobler, among which we highlight the structuring skills of the teaching-learning process, such as the knowledge acquired when reading, writing and calculating. It is also important to point out that the school has an important role establishing success in different fractions of the class, establishing a relationship between the knowledge acquired on school context and the cultural capital inherited on the family environment.

The term "class fractions" means a group of individuals who share the same economic, cultural capital and are similar in their attitudes towards society, consequently, their social conditions are similar.

According to Nogueira and Nogueira (2002), Bourdieu describes the term asceticism as something that would be characterised by the disposition of the middle classes renouncing certain pleasures and immediate needs when expecting their future. Such sacrifices can be verified when opting spending less on material goods and aiming to guarantee good schooling by giving priority to their offspring studies.

Malthusianism would be the propensity to control fertility. In middle-class families, due to an unconscious investment of strategy concentration, would tend to reduce the number of children more than families in popular and elite classes. Bourdieu noted that statistics prove that the opportunities for a longer school life are closely associated with family size when all other variables are controlled. Finally, cultural goodwill would be characterised by 
the recognition of legitimate culture and the systematic effort to acquire it (NOGUEIRA; NOGUEIRA, 2002, p. 25, our translation) ${ }^{11}$.

Nogueira and Nogueira (2002) also describe how middle-class families have or consider limited cultural capital, thus having the need of material and consuming goods such as books, tours, cultural events or even symbols that refer to a legitimated cultural capital seeking to enrich and appropriate this to achieve social ascension.

Although it can be said that the aspiration for social ascension leads to a tendency to invest heavily on children education, it must not be forgotten that the degree to which this occurs would depend on the relative weight of capital in each of the middle class' fractions (NOGUEIRA; NOGUEIRA, 2002, p. 25 , our translation) $)^{12}$.

The fractions of classes most provided with economic capital tend not to grant school investment as a primacy, going on the opposite way to those that almost exclusively hold cultural capital.

It is necessary to note that the greater or lesser trend for school investment would be related to the upward or downward trajectory of the middle-class fraction in question. The ascending groups would be the ones who place great hopes on their children's schooling (NOGUEIRA; NOGUEIRA, 2002, p. 25 , our translation $)^{13}$.

Regarding cultural and economic elites, Bourdieu (NOGUEIRA; NOGUEIRA, 2002), claims that they would tend to invest intensively in the school institution in a non-methodical way, considering that the legitimate cultural capital assumed by the school is naturally similar to the one experienced in their family. Following this line of thought, "The objective conditions of possessing an expressive volume of economic, social and cultural capital would make school

\footnotetext{
${ }^{11}$ O malthusianismo seria a propensão ao controle da fecundidade. As famílias de classe média, por uma estratégia inconsciente de concentração dos investimentos, tenderiam, mais do que as das classes populares e mesmo do que as das elites, a reduzir o número de filhos. Bourdieu observa que, de fato, as estatísticas comprovam que as oportunidades de uma vida escolar mais longa estão intimamente associadas - quando se controla todas as outras variáveis - ao tamanho da família. Finalmente, a boa vontade cultural se caracterizaria pelo reconhecimento da cultura legítima e pelo esforço sistemático para adquiri-la (NOGUEIRA; NOGUEIRA, 2002, p. 25).

${ }^{12}$ Embora, de um modo geral, possa se falar que a aspiração por ascensão social, que caracteriza as classes médias, conduz à tendência de se investir fortemente na escolarização dos filhos, não se pode esquecer que o grau em que isso ocorre dependeria do peso relativo dos capitais em cada uma das frações da classe média (NOGUEIRA; NOGUEIRA, 2002, p. 25).

${ }^{13}$ É necessário observar, também, que a tendência maior ou menor ao investimento escolar estaria relacionada com a trajetória ascendente ou descendente da fração de classe média em questão. Os grupos ascendentes seriam os que depositariam maiores esperanças na escolarização de seus filhos ((NOGUEIRA; NOGUEIRA, 2002, p. 25, 2002, p. 25).
} 
failure very unlikely" (NOGUEIRA; NOGUEIRA, 2002, p. 25, our translation) mainly because they already occupy a position of control on society, thus not needing to fight for the social ascension so desired by the middle classes.

Bourdieu also highlights the fact that there is a distinction between the richest in economic capital and the richest in cultural capital, where the latter would aim at greater investment in longer and more promising school careers, while the former would tend to strive for legitimate certifications that guarantee their position of prestige, social and economic dominance.

The school continually eliminates students from less favoured backgrounds and who culminate in cultural obstacles, perceived in differences in attitudes and skills significantly linked to social origin (BOURDIEU, 1964).

Therefore, the social space is marked by successful school performance in different fractions of the class, in which the agents have points of view according to the position they occupy, expressing their willingness to transform or preserve them. It is clear that a successful school trajectory also depends on acquiring power and the friendship bonds created during their path.

The school indeed perpetuates social inequalities, but if an identity-building exercise is initiated within the family, guaranteeing freedom and security to our children and teenagers identities', the school institution will continue to reproduce the dynamism and social movement. However, this movement will be given by conscientious people, who are fighting for their rights (OLIVEIRA et al., 2017, p. 103, our translation) ${ }^{14}$.

Thus, education must be oriented towards a free and creative culture and while real effective, contributing to the full training of individuals to exercise their role in the decisions of the society in which they live.

\footnotetext{
${ }^{14}$ É certo que a escola perpetua as desigualdades sociais e, por consequente todas as relações sociais, porém, se houver um exercício de construção de identidade iniciado no seio familiar, que, garanta às nossas crianças e adolescentes uma liberdade e segurança em relação às suas identidades, a instituição escolar continuará reproduzindo a dinamicidade e movimento social, porém este movimento será dado por pessoas conscientes, que lutam justamente por seus direitos (OLIVEIRA et al., 2017, p. 103).
} 


\section{METHODOLOGY}

This work was developed at a public school on the countryside of the São Paulo state, in the third-grade high school classes, with an audience of approximately two hundred and fifty students. We collected the data through a case study.

The observation took place through the use of certain aspects of school's reality, with the aim of bringing characteristics of family customs that influenced students' school performance. Based on the observed reality, the different conceptions and behaviours towards the school institution were analyzed.

The reason for choosing the Bourdieusian praxeology of qualitative basis was its internally and externally relations to apprehend the subject's nature for structuring habitus. The Bourdieusian praxeology is defined as knowledge aiming to analyse the objective relations system which is built by the objectivist knowledge method, the argumentative relations between these structures and the structured dispositions in which they are updated and tend to reproduce.

[...] praxiological knowledge inverts objectivist knowledge, questioning the possible conditions of this topic (theoretical and social conditions) showing at the same time, that objectivist knowledge is fundamentally defined by excluding this topic: as far as it constitutes itself into the first experience practical apprehension of the social world - objectivist knowledge moves away from the construction of the social world's practical knowledge theory and allowing the lack of it by producing theoretical knowledge of the social world versus its implicit assumptions of practical knowledge. Praxiological knowledge does not nullify the acquisition of objectivist knowledge but preserves and surpasses them, integrating what that knowledge excluded to obtain them (BOURDIEU, 1983, p. 47, our translation) $)^{15}$.

\section{ANALYSIS AND DISCUSSION}

The work shows that the participation of the family during the teaching process is not the only guarantee factor for a successful school performance considering the cultural aspects cultivated in the family environment, such as their reading habit. Museums visits; appreciation

\footnotetext{
15 [...] o conhecimento praxiológico inverte o conhecimento objetivista, colocando a questão das condições de possibilidade dessa questão (condições teóricas e, também, sociais) e mostra, ao mesmo tempo, que o conhecimento objetivista se define fundamentalmente, pela exclusão dessa questão: na medida em que ele se constitui contra a experiência primeira - apreensão prática do mundo social - o conhecimento objetivista se afasta da construção da teoria do conhecimento prático do mundo social e dela produz, ao menos negativamente, a falta, ao produzir conhecimento teórico do mundo social contra os pressupostos implícitos do conhecimento prático do mundo social. O conhecimento praxiológico não anula as aquisições do conhecimento objetivista, mas conservaas e as ultrapassa, integrando o que esse conhecimento teve que excluir para obtê-las (BOURDIEU, 1983, p. 47).
} 
of theatrical performances are also important factors that contributed to acquiring knowledge, as pointed out by Thin (2006, p. 212, our translation $)^{16}$, on their studies.

The cultural capital is a valuable indicator when it comes to classifying social subjects and their cultural and educational practices to compare and situate them concerning each other. However, it does not restore or summarize the diversity and complexity of practices. It neglects parents' effective relations with the school, how parents appropriate their children's education, the meaning they attribute and the level of the parents or guardians' education.

It was observed that the causes of a successful school performance are related to individual interpretations through important factors while acquiring knowledge. According to studies by Garcia (2013), it is defined as the attribution of causality.

The theory of causality is explained by the individual's attitudes in the environment which is inserted, manifesting itself in response to the actions presented in the environment in which they live. In schools, these attitudes correspond to the results obtained by students throughout the year. Here we observe the theory of causality as a tendency of the individual, to quantify and explain the facts that have occurred.

This theory influences the different rates of acquiring knowledge as individual actions are the result of different material, social, economic and cultural conditions of each social class. The relative autonomy of each individual through the relations of social classes with the school itself internalises knowledge.

The acquisition of knowledge had different trajectories, as access to culture and family monitoring were present at different times and intensities, showed in Table 1. The different cultural activities experienced at the school are described on the left. On the right the number of students who participated in these activities is described.

Table 1 - Cultural activities provided by the school

\begin{tabular}{|l|l|}
\hline Cultural activities provided by the school & Number of students \\
\hline
\end{tabular}

\footnotetext{
${ }^{16} \mathrm{O}$ capital cultural é certamente um indicador valioso quando se trata de classificar os sujeitos sociais e suas práticas culturais e educativas, compará-los, situá-los uns em relação aos outros, mas não permite, por si só restituir ou resumir a diversidade e a complexidade das práticas. Ele deixa de lado as relações efetivas dos pais com a escola, a forma como os pais se apropriam da escolaridade de seus filhos, o sentido que eles atribuem, grau de instrução dos pais ou responsáveis (THIN, 2006, p. 212).
} 


\begin{tabular}{|l|c|}
\hline Different musical styles (class change signal) & 48 \\
\hline Sporty practices & 06 \\
\hline Artistic activities (dancing, drawings, cultural competitions) & 25 \\
\hline Theatre performances & 17 \\
\hline Access to different literary genres (library) & 17 \\
\hline Typical dishes (lunch) & 16 \\
\hline Artworks & 11 \\
\hline Films & 16 \\
\hline Lectures & 03 \\
\hline Museums & 01 \\
\hline
\end{tabular}

The analysis of these data shows that the best results in the evaluation processes are the effects of restructuring the habitus, provided by the diversified cultural activities and the domination of symbolic codes. The mastery of these codes is fundamental within a legitimate or literate culture for the sake of appreciating works of art, theatrical performances and diversified musical styles.

It is on the school space that individual differences become visible, representing choices that can reduce or increase students' dependence on their social origin, breaking or tightening the automatic conversion chain of differences (material and cultural, family and class) toward school success or failure (CARVALHO, 2000).

It was necessary to analyse in detail the objective relationship that is at the principle of double effectiveness to apprehend in all its complexity the specific mechanisms by which the school system produces its technical effects and its properly symbolic effects, i.e., the relationship between the objective characteristics of the organization and the socially constituted dispositions of the agents (BOURDIEU, 2015, p. 22, our translation) ${ }^{17}$.

In this way, the school will convert the acquired cultural heritage into the family's qualifications and diplomas considered socially recognized credentials.

\section{FINAL CONSIDERATIONS}

\footnotetext{
${ }^{17}$ Foi necessário analisar em detalhe a relação objetiva que está no princípio da dupla eficácia para apreender em toda sua complexidade os mecanismos específicos pelos quais o sistema escolar produz seus efeitos técnicos e seus efeitos propriamente simbólicos, ou seja, a relação entre as características objetivas da organização escolar e as disposições socialmente constituídas dos agentes (BOURDIEU, 2015, p. 22).
} 
The educational results show that although the school allows all individuals to have contact with higher cultural practices, including the acquisition of cultured language and mathematical mastery, we still perceive gaps in the ideals of high quality education for all.

Even though the school contributes to the acquisition of cultural capital - through pedagogical practices that allow students to contact the work of arts, books, exhibitions, visits to museums and theaters -, these experiences will only be incorporated into the cultural heritage inherited in the family by acquiring knowledge.

The result of these practices is the outcome of the socialization process developed by habits, values, beliefs and knowledge considered necessary to families for the insertion of their children in society, transmitting these values from generation to generation.

Therefore, the development of the child will be constituted in the family through the affective relationships experienced; contributing to the perception of human behaviour. The family is essential even though there are still cases in which the school are the only places to access diverse cultural resources not shared in the family environment due to the precariousness of economic resources, such as books, computers, plays, different kinds of music.

In reality, each family indirectly transmits to their children certain cultural capital and ethos (an implicit and deeply internalised value systems), helping to define attitudes facing cultural capital and school institution (BOURDIEU, 2003$, p. 41 , our translation $)^{18}$.

The role of educational institutions is also fundamental on this development process so that both school and family mutually look at the child as the main element of educational action. Bourdieu (1998, p. 4, our translation $)^{19}$ explains that:

We likely continue to consider the school system as a factor of social mobility, according to the liberating school ideology. However, when everything tends to show that this is one of the most effective factors of social conservation,

\footnotetext{
${ }^{18} \mathrm{Na}$ realidade, cada família transmite a seus filhos, mais por vias indiretas que diretas, um certo capital cultural e um certo ethos, sistema de valores implícitos e profundamente interiorizados, que contribui para definir, entre coisas, as atitudes face ao capital cultural e à instituição escolar (BOURDIEU, 2003, p .41).

${ }^{19}$ É provável que continuamos tomando o sistema escolar como um fator de mobilidade social, segundo a ideologia da escola libertadora, quando ao contrário, tudo tende a mostrar que ele é um dos fatores mais eficazes de conservação social, pois fornece a aparência de legitimidade às desigualdades sociais, e sanciona a herança cultural e o dom social tratado como dom natural (BOURDIEU, 1998, p. 4).
} 
as it provides the appearance of legitimacy to inequalities and endorses cultural heritage and social benefits treated as natural gifts.

It will be up to the school promoting the acquisition of knowledge while the family socializes the individual by transmitting values and attitudes got as cultural heritage. The school's responsibility is not only transmitting fundamental knowledge to acquire knowledge, but also the integral formation of the individual, leading them to become a critical and participative citizen living in society.

In this sense, the school should be characterised as an institution that holds knowledge and practices which aim the cultural enrichment of its students in an equal way, demystifying the myth of gift and vocation imposed by a society structurally based on relations of dominated and dominant. Thus, it is expected that the school institution should be a form to seek an emancipatory education. rather than transmitting content, exempting itself from the historically established function of a social inequalities perpetrator.

\section{REFERENCES}

BLOOM, Benjamin Samuel; HASTINGS, John Thomas; MADAUS, George Fowler. Manual de avaliação formativa e somativa do aprendizado escolar. São Paulo: Livraria Pioneira Editora, 1983. p. 67-97.

BOURDIEU, Pierre. A Escola Conservadora: as desigualdades frente à escola e à cultura. In: BOURDIEU, Pierre. Escritos da Educação. Petrópolis: Vozes, 2003. p. 41-79.

BOURDIEU, Pierre. A escola conservadora: as desigualdades frente à escola e à cultura. In: BOURDIEU, Pierre. Escritos de educação. Trad. Maria Alice Nogueira e Afrânio Catani. Rio de Janeiro: Vozes, 1998. p. 04-69.

BOURDIEU, Pierre. Espaço social e poder simbólico. In: BOURDIEU, Pierre. Coisas ditas. Trad. Cássia Rodrigues da Silveira e Denise Moreno Pegorim. São Paulo: Brasiliense, 1990. p. 149168.

BOURDIEU, Pierre. Gosto de classe e estilo de vida. In: ORTIZ, Renato (Org.). Sociologia. v. 39. São Paulo: Ática, 1983.

BOURDIEU, Pierre. Provação escolar e consagração social. As classes preparatórias para as grandes escolas. Revista Tempos e Espaços em Educação, v. 8, n. 15, p. 19-120, 2015. Disponível em: https://seer.ufs.br/index.php/revtee/article/view/3665 Acesso em: 10 jun. 2020.

BOURDIEU, Pierre; PASSERON, Jean-Claude. A reprodução. Elementos para uma teoria do sistema de ensino. Trad. Reynaldo Bairão; Rev. Pedro Benjamim Garcia e Ana Maria Baeta. 3. ed. São Paulo: Francisco Alves, 1992. p. 15-77. 
BOURDIEU, Pierre; Passeron, PASSERON, Jean-Claude. Les héritiers: les étudiants et la culture. Paris: Minuit, 1964. p. 19-22.

CARMIGNOLLI, Andreza Olivieri Lopes. A influência dos capitais cultural, social e econômico no sucesso da trajetória escolar. 2019. 60 f. Dissertação (Mestrado em Educação Escolar) Faculdade de Ciências e LetrasUniversidade Estadual Paulista, Araraquara, 2019.

CARVALHO, Mauro Giffoni. Educação, comunicação e sexualidade: a realidade engendrada na escola. 2000. 181 f. Tese (Doutorado em Comunicação e Cultura) - Programa de PósGraduação da Escola de Comunicação, Universidade Federal do Rio de Janeiro, Rio de Janeiro, 2000.

GARCIA, Natália Rodovalho. Atribuições de causalidade para sucesso e fracasso escolar e resiliência em estudantes do ensino fundamental. 1985. Disponível em:

http://repositorio.unicamp.br/jspui/. Acesso em: 05 mar. 2018.

GRÜN, Roberto. Capital econômico. In: CATANI, Afrânio Mendes; NOGUEIRA, Maria Alice; HEY, Ana Paula; MEDEIROS, Cristina De. de (Orgs.). Vocabulário Bourdieu. Belo Horizonte: Autêntica Editora, 2017. p. 107-109.

KINCHESCKI, Ana Paula de Souza, GRIMM, Viviane; SOSSAI, Fernando Cesar. Escola, violência simbólica e meritocracia em grupos escolares do Sul de Santa Catarina: algumas reflexões a partir de Pierre Bourdieu. Revista Tempos e Espaços em Educação, v. 8, n. 15, p. 245-256, 2015. Disponível em: https://seer.ufs.br/index.php/revtee/article/view/3678

LEBARON, Frédéric. Capital. In: CATANI, Afrânio Mendes; NOGUEIRA, Maria Alice; HEY, Ana Paula; MEDEIROS, Cristina De (Orgs.). Vocabulário Bourdieu. Belo Horizonte: Autêntica Editora, 2017. p. 101-103.

MANZAN, Willian Alexandre; MUZZETI, Luci Regina; SUFICIER, Darbi Masson. A observação do habitus primário: um estudo de caso. Revista Ibero-Americana de Estudos em Educação, v. 7, p. 1-11, 2012. Disponível em:

https://periodicos.fclar.unesp.br/iberoamericana/article/view/6294/4704. Acesso em: 09 jun. 2020.

MASSI, Luciana; MUZZETI, Luci Regina; SUFICIER, Darbi. A pesquisa sobre trajetórias escolares no Brasil. Revista Ibero-Americana de Estudos em Educação, v. 12, n. 3, p. 18541873, jul./set. 2017. Disponível em: https://periodicos.fclar.unesp.br/iberoamericana/issue/view/643/showToc. Acesso em: 09 jun. 2020.

MELO, Marilândes Mól Ribeiro de. Ensaio sobre socialização: incursões em noções de Pierre Bourdieu. Revista Tempos e Espaços em Educação, v. 8, n. 15, p. 193-206, 2015. Disponível em: https://seer.ufs.br/index.php/revtee/article/view/3674/3131 . Acesso em: 10 jun. 2020. 
NOGUEIRA, Cláudio Marques Martins; NOGUEIRA, Maria Alice. A Sociologia Da Educação De Pierre Bourdieu: limites e contribuições. Educação \& Sociedade, ano XXIII, n. 78, abr. 2002.

OLIVEIRA, Maria Fernanda Celli de; MUZETTI, Luci Regina; MICHELETI, Laís Inês Sanseverinato; LEÃO, Andreza Marques de Castro. Dominação Masculina: A construção histórica materializada em herança social e cultural. Revista CAMINE: Caminhos da Educação, Franca, v. 9, n. 1, 2017.

SANTOS, Leonor. A articulação entre a avaliação somativa e a formativa, na prática pedagógica: uma impossibilidade ou um desafio? Ensaio: aval. pol. públ. Educ., Rio de Janeiro, v. 24, n. 92, p. 637-669, jul./set. 2016.

THIN, Daniel. Para uma análise das relações entre famílias populares e escola: confrontação entre lógicas socializadoras. Revista Brasileira de Educação, v. 11, n. 32, p.211-225, maio/ago. 2006.

\section{$\underline{\text { ABOUT THE AUTHORS }}$}

\section{Andreza Olivieri Lopes Carmignolli}

Doctoral student of the Postgraduate Program in School Education, São Paulo State University (UNESP); Faculty of Sciences and Languages (FCLAr/UNESP) - Brazil. Member of the Center for Sexuality Studies - NUSEX.

E-mail: carmignolli@hotmail.com

ORCID: https://orcid.org/0000-0001-5593-9793

\section{Luci Regina Muzzeti}

Habilitation in Sociology of Education and Professor of the Postgraduate Program in School Education, São Paulo State University (UNESP); Faculty of Sciences and Languages (FCLAr/UNESP) - Brazil. Department of Education. Member of the Center for Sexuality Studies - NUSEX.

E-mail: luci.muzzeti@unesp.br

ORCID: https://orcid.org/0000-0002-6808-2490

\section{Maria Fernanda Celli de Oliveira}

Doctoral student of the Postgraduate Program in School Education, São Paulo State University (UNESP); Faculty of Sciences and Languages (FCLAr/UNESP) - Brazil. Substitute professor at the Department of Education. Member of the Center for Sexuality Studies - NUSEX. CAPES Doctoral Scholar.

E-mail: maria-fernanda-co@hotmail.com

ORCID: https://orcid.org/0000-0001-6358-7986

Received in: 07-13-2020. Approved in: 09-15-2020. Published in: 10-07-2020. 